\title{
Crown years for non-invasive cardiovascular imaging (Part III): 30 years cardiovascular magnetic resonance
}

\author{
E. E. van der Wall
}

Published online: 9 April 2013

(C) The Author(s) 2013. This article is published with open access at Springerlink.com

2013 is a remarkable year in cardiovascular medicine from a historical point of view. It can be considered a crown year for non-invasive clinical cardiovascular imaging as we can look back on 60 years of echocardiography, 40 years of nuclear cardiology, 30 years of cardiovascular magnetic resonance imaging, and 30 years of cardiac computed tomography. In previous Editor's Comments, 60 years of echocardiography and 40 years of nuclear cardiology were described (Parts I and II) $[1,2]$. In this Editor's Comment (Part III) we will briefly look back to the roots of cardiovascular magnetic resonance imaging and its main achievements.

\section{Cardiovascular magnetic resonance 30 years}

The year 1983 was a major breakthrough for cardiovascular nuclear magnetic resonance (NMR). For the first time, various research groups around the world addressed the huge clinical potential of NMR in cardiovascular disease [3-7]. At that time, Burdine and Murphy (Texas Heart Institute, USA) stated that 'magnetic resonance cardiac imaging is an exciting new diagnostic modality in which acceptance as a routine diagnostic tool depends on the results of extensive clinical trials' [7]. In order to eliminate the word 'nuclear', with its unpopular public connotation, the name was changed from NMR to MR imaging or MRI. Later on, cardiovascular

E. E. van der Wall $(\bowtie)$

Interuniversity Cardiology Institute of the Netherlands

(ICIN) - Netherlands Heart Institute (NHI), Catherijnesingel 52,

P.O. Box 19258, 3501 DG, Utrecht, the Netherlands

e-mail: e.e.van_der_wall@lumc.nl

E. E. van der Wall

e-mail: ernst.van.der.wall@icin.knaw.nl
MRI changed into cardiovascular magnetic resonance (CMR). Over the past 30 years, there have been major technical developments in CMR which have resulted in improved image quality allowing the accurate diagnosis and prognosis in patients with a wide spectrum of cardiovascular diseases such as coronary artery disease, cardiomyopathies, myocarditis, valvular heart disease, and congenital heart disease.

In 1984, the first CMR machine was installed in the Netherlands (Leiden). In the same year, first moving (cine) images of the heart by CMR were reported permitting the visualisation of wall motion abnormities [8]. CMR enabled the calculation of left ventricular volumes and ejection fraction [9], which turned out be accurate, reliable and reproducible [10]. In 1988, the Leiden group was one of the first to apply contrast-enhanced imaging using gadoliniumDTPA in patients following acute myocardial infarction [11]. The signal intensity ratio of infarcted versus normal myocardium was significantly greater after the administration of gadolinium DTPA improving the detection and localisation of infarct zones by CMR. From that moment on, myocardial tissue characterisation by virtue of contrast enhancement has obtained a fixed niche in CMR imaging [12-16]. In a landmark study using gadolinium-enhanced CMR in 50 patients with ventricular dysfunction, Kim et al. (Chicago, USA) showed that reversible myocardial dysfunction could be identified by contrast-enhanced CMR before coronary revascularisation [13]. The group directed by Sechtem (Stuttgart, Germany) showed that localised contrast enhancement was a frequent finding in the clinical setting of suspected myocarditis associated with active inflammation defined by histopathology [14]. Using contrastenhanced CMR, the Amsterdam VUmc group directed by Van Rossum showed the presence of localised crypts in the inferoseptal left ventricular wall in patients with subclinical 
hypertrophic cardiomyopathy [15]. A recent study in patients with newly diagnosed non-ischaemic cardiomyopathy showed that contrast-enhanced-positive patients had a worse prognosis than patients without signs of contrast enhancement [16].

In the late 1980s CMR myocardial tagging was introduced, being a new alternative method for non-invasive assessment of myocardial motion. In addition to simple translation and rotation, complex motions such as cardiac twist and left ventricular torsion could be demonstrated [17, 18].

In the 1990s, CMR underwent further developments. In 1990, myocardial perfusion imaging by first-pass contrastenhanced CMR was introduced based on the transit of gadolinium-DTPA through the cardiac chambers and myocardium [19]. After induction of vasodilation by either adenosine or dipyridamole, first-pass perfusion CMR imaging could be performed during intravenous bolus injection of a gadolinium-based contrast agent in order to detect perfusion defects in the ischaemic area [20]. In 1991, Manning's group (Boston, USA) was one of the first to show the potential of CMR imaging of the coronary arteries using breath-hold imaging techniques [21]. From that time on, coronary MR angiography allowed the detection of coronary artery stenosis [22]. In addition, it became possible to evaluate the functional status of coronary artery bypasses using high-resolution magnetic resonance angiography [23]. In 1992, Pennell's group (London, UK) reported the first use of left ventricular wall motion analyses during dobutamine stress CMR in 25 patients with exertional chest pain [24]. Dobutamine stress CMR was compared with thallium-201 single photon emission tomography (SPECT) showing a $90 \%$ agreement between SPECT and dobutamine stress CMR for identifying myocardial ischaemia. In 1994, it was shown that dobutamine CMR clearly identified wall motion abnormalities by quantitative analysis using a modification of the centreline method, developed by Reiber's group (Leiden, NL) [25]. In one of the first prognostic dobutamine CMR studies, Kuijpers and Van Dijkman (The Hague, NL) reported a positive and negative predictive value of $95 \%$ and $93 \%$, respectively, for identifying major adverse cardiac events by dobutamine CMR imaging.

Apart from its value in coronary artery disease, CMR has established a fixed niche in patients with structural and congenital heart disease [26-29]. Using velocity mapping techniques it was shown that CMR was well suited to detect changes in aortic stiffness by measuring distensibility and pulse wave velocity, for example in the Marfan syndrome [29].

From 2000 on, newer CMR techniques involving realtime imaging and 3-D data acquisitions with parallel imaging have increased efficiency in data acquisition. The increased availability of 3 Tesla MRI scanners provided an enhanced signal which increased the applications in general clinical practice [30-34]. Developments in contrast agents and molecular imaging agents further extended the potential applications of CMR. In recent years, CMR allowed the characterisation of plaque composition, i.e. the discrimination of lipid core, fibrosis, calcification, and intra-plaque haemorrhage deposits [35]. Identification of subclinical atherosclerosis and early treatment initiation has the potential to surpass conventional risk factor assessment and management in terms of overall impact on cardiovascular morbidity and mortality.

In summary, over the past 30 years CMR has evolved into an extremely useful diagnostic modality in cardiovascular disease. It offers new insights into cardiac pathophysiology and aids in the diagnosis of a wide spectrum of cardiovascular diseases. Although a single CMR exam may provide a comprehensive assessment for aetiologies of various cardiovascular diseases, hybrid imaging may become more informative and cost-effective in the long run [36-39]. With expanding expertise and recognition of its diagnostic and prognostic power, CMR will grow in importance in the armamentarium of the cardiac imager for years to come.

N.B. This Editors comment highlights only a selected number of achievements in CMR. For a more detailed description of the achievements by CMR the reader is referred to more in-depth publications [40-43].

Open Access This article is distributed under the terms of the Creative Commons Attribution License which permits any use, distribution, and reproduction in any medium, provided the original author(s) and the source are credited.

\section{References}

1. van der Wall EE. Crown years for noninvasive cardiovascular imaging (part I): 60 years of echocardiography. Neth Heart J. 2013;21:161-2. doi:10.1007/s12471-013-0381-3.

2. van der Wall EE. Crown years for noninvasive cardiovascular imaging (part II): 40 years of nuclear cardiology. Neth Heart J. 2013. doi:10.1007/s12471-013-0392-0.

3. Kaufman L, Crooks L, Sheldon P, et al. The potential impact of nuclear magnetic resonance imaging on cardiovascular diagnosis. Circulation. 1983;67:251-7.

4. Pohost GM, Ratner AV, Okada RD. Proton NMR imaging: a new approach for the evaluation of cardiac structure and function. Int $\mathrm{J}$ Cardiol. 1983;4:87-94.

5. Higgins $\mathrm{CB}$, Botvinick EH, Lanzer $P$, et al. Cardiovascular imaging with nuclear magnetic resonance. Cardiol Clin. 1983;1:527-39.

6. Steiner RE, Bydder GM, Selwyn A, et al. Nuclear magnetic resonance imaging of the heart. Current status and future prospects. Br Heart J. 1983;50:202-8.

7. Burdine JA, Murphy PH. Cardiac imaging by nuclear magnetic resonance. Tex Heart Inst J. 1983;10:45-8.

8. Waterton JC, Jenkins JP, Zhu XP, et al. Magnetic resonance (MR) cine imaging of the human heart. Br J Radiol. 1985;58:711-6.

9. van Rossum AC, Visser FC, van Eenige MJ, et al. Magnetic resonance imaging of the heart for determination of ejection fraction. Int J Cardiol. 1988;18:53-63.

10. Bavelaar-Croon CD, Kayser HW, van der Wall EE, et al. Left ventricular function: correlation of quantitative gated SPECT and 
MR imaging over a wide range of values. Radiology. 2000;217:5725.

11. de Roos A, Doornbos J, van der Wall EE, et al. MR imaging of acute myocardial infarction: value of Gd-DTPA. AJR Am J Roentgenol. 1988;150:531-4.

12. van Dijkman PR, van der Wall EE, de Roos A, et al. Acute, subacute, and chronic myocardial infarction: quantitative analysis of gadolinium-enhanced MR images. Radiology. 1991;180:147-51.

13. Kim RJ, Wu E, Rafael A, et al. The use of contrast-enhanced magnetic resonance imaging to identify reversible myocardial dysfunction. N Engl J Med. 2000;343:1445-53.

14. Mahrholdt H, Goedecke C, Wagner A, et al. Cardiovascular magnetic resonance assessment of human myocarditis: a comparison to histology and molecular pathology. Circulation. 2004;109:1250-8.

15. Germans T, Wilde AA, Dijkmans PA, et al. Structural abnormalities of the inferoseptal left ventricular wall detected by cardiac magnetic resonance imaging in carriers of hypertrophic cardiomyopathy mutations. J Am Coll Cardiol. 2006;48:2518-23.

16. Müller KA, Müller I, Kramer U, et al. Prognostic Value of Contrastenhanced Cardiac Magnetic Resonance Imaging in Patients with Newly Diagnosed Non-Ischemic Cardiomyopathy: Cohort Study. PLoS One. 2013;8:e57077. doi:10.1371/journal.pone.0057077.

17. Zerhouni EA, Parish DM, Rogers WJ, et al. Human heart: tagging with MR imaging-a method for noninvasive assessment of myocardial motion. Radiology. 1988;169:59-63.

18. Kuijer JP, Marcus JT, Götte MJ, et al. Variance components of twodimensional strain parameters in the left-ventricular heart wall obtained by magnetic resonance tagging. Int $\mathrm{J}$ Cardiovasc Imaging. 2001;17:49-60.

19. Atkinson DJ, Burstein D, Edelman RR. First-pass cardiac perfusion: evaluation with ultrafast MR imaging. Radiology. 1990;174:75762.

20. Matheijssen NA, Louwerenburg HW, van Rugge FP, et al. Comparison of ultrafast dipyridamole magnetic resonance imaging with dipyridamole SestaMIBI SPECT for detection of perfusion abnormalities in patients with one-vessel coronary artery disease: assessment by quantitative model fitting. Magn Reson Med. 1996;35:221-8.

21. Edelman RR, Manning WJ, Burstein D, et al. Coronary arteries: breath-hold MR angiography. Radiology. 1991;181:641-3.

22. van der Wall EE, Vliegen HW, de Roos A, et al. Magnetic resonance imaging in coronary artery disease. Circulation. 1995;92:2723-39.

23. Langerak SE, Vliegen HW, de Roos A, et al. Detection of vein graft disease using high-resolution magnetic resonance angiography. Circulation. 2002;105:328-33.

24. Pennell DJ, Underwood SR, Manzara CC, et al. Magnetic resonance imaging during dobutamine stress in coronary artery disease. Am J Cardiol. 1992;70:34-40.

25. van Rugge FP, van der Wall EE, Spanjersberg SJ, et al. Magnetic resonance imaging during dobutamine stress for detection and localization of coronary artery disease. Quantitative wall motion analysis using a modification of the centerline method. Circulation. 1994;90:127-38.

26. Kilner PJ, Geva T, Kaemmerer H, et al. Recommendations for cardiovascular magnetic resonance in adults with congenital heart disease from the respective working groups of the European society of cardiology. Eur Heart J. 2010;31:794-805. doi:10.1093/eurheartj/ehp586.
27. Joziasse IC, Vink A, Cramer MJ, et al. Bicuspid stenotic aortic valves: clinical characteristics and morphological assessment using MRI and echocardiography. Neth Heart J. 2011;19:119-25.

28. Rebergen SA, Ottenkamp J, Doornbos J, et al. Postoperative pulmonary flow dynamics after Fontan surgery: assessment with nuclear magnetic resonance velocity mapping. J Am Coll Cardiol. 1993;21:123-31.

29. Groenink M, de Roos A, Mulder BJ, et al. Changes in aortic distensibility and pulse wave velocity assessed with magnetic resonance imaging following beta-blocker therapy in the Marfan syndrome. Am J Cardiol. 1998;82:203-8.

30. Lexis CP, Rahel BM, van Langen $\mathrm{H}$, et al. Cardiac magnetic resonance imaging in daily practice in a peripheral medical centre: description of the first 383 patients. Neth Heart J. 2010;18:524-30.

31. Luijkx T, Cramer MJ, Zaidi A, et al. Ethnic differences in ventricular hypertrabeculation on cardiac MRI in elite football players. Neth Heart J. 2012;20:389-95. doi:10.1007/s12471-012-0305-7.

32. Olimulder MA, Galjee MA, van Es J, et al. Contrast-enhancement cardiac magnetic resonance imaging beyond the scope of viability. Neth Heart J. 2011;19:236-45. doi:10.1007/s12471-011-0084-6.

33. Freling HG, van Slooten YJ, van Melle JP, et al. Prosthetic valves in adult patients with congenital heart disease: Rationale and design of the Dutch PROSTAVA study. Neth Heart J. 2012;20:419-24.

34. Robbers LF, Nijveldt R, Beek AM, et al. Intracoronary infusion of mononuclear cells after PCI-treated myocardial infarction and arrhythmogenesis: is it safe? Neth Heart J. 2012;20:133-7.

35. Corti R, Fuster V. Imaging of atherosclerosis: magnetic resonance imaging. Eur Heart J. 2011;32:1709-19. doi:10.1093/eurheartj/ehr068.

36. Marcu CB, Beek AM, Ionescu CN, et al. Double orifice mitral valve visualized on echocardiography and MRI. Neth Heart J. 2012;20:380-1. doi:10.1007/s12471-011-0149-6.

37. Schwitter J, Wacker CM, Wilke N, et al. Magnetic Resonance Imaging for Myocardial Perfusion Assessment in Coronary artery disease Trial: perfusion-cardiac magnetic resonance vs. singlephoton emission computed tomography for the detection of coronary artery disease: a comparative multicentre, multivendor trial. Eur Heart J. 2013;34:775-81. doi:10.1093/eurheartj/ehs022.

38. van der Wall EE. Myocardial perfusion imaging in coronary artery disease: SPECT, PET or CMR? Neth Heart J. 2012;20:297-8. doi:10.1007/s12471-012-0300-z.

39. Rischpler C, Nekolla SG, Dregely I, et al. Hybrid PET/MR Imaging of the heart: potential, initial experiences, and future prospects. J Nucl Med. 2013;54:402-15. doi:10.2967/jnumed.112.105353.

40. Underwood SR, Bax JJ, Vom Dahl J, et al. Imaging techniques for the assessment of myocardial hibernation. Report of a Study Group of the European Society of Cardiology. Eur Heart J. 2004;25:81536.

41. Gerber BL, Raman SV, Nayak K, et al. Myocardial first-pass perfusion cardiovascular magnetic resonance: history, theory, and current state of the art. J Cardiovasc Magn Reson. 2008;10:18. doi:10.1186/1532-429X-10-18.

42. Charoenpanichkit C, Hundley WG. The 20 year evolution of dobutamine stress cardiovascular magnetic resonance. J Cardiovasc Magn Reson. 2010;12:59. doi:10.1186/1532-429X-12-59.

43. Kirschbaum SW, de Feyter PJ, van Geuns RJ. Cardiac magnetic resonance imaging in stable ischaemic heart disease. Neth Heart J. 2011;19:229-35. doi:10.1007/s12471-011-0106-4. 